\title{
Career Role Analysis of Civil Servants at the State Employment Agency
}

\author{
Ary Herwanto \\ Faculty of Social and Political Sciences \\ Universitas Indonesia \\ Depok, Indonesia \\ aryarifqa@gmail.com
}

\author{
Amy Yayuk Sri Rahayu \\ Faculty of Social and Political Sciences \\ Universitas Indonesia \\ Depok, Indonesia \\ amy_soeroso@yahoo.com
}

\begin{abstract}
This study aimed to analyse the career role guidance and consouling of civil servants at the State Employment Agency in Jakarta and related efforts for their empowerment. The study employs a postpositivist approach by testing the theories on career consouling by collecting qualitative data through indepth interviews and by conducting literature studies, application of a triangulation strategy for validating and verifying the available data. The study's findings reveal that, first, that the notion of consouling plagued by a misperception consouling about person with a mental or psychological problem as opposed to guidance and consouling for person at the moment facing an impasse in their career and assisting to achieve their best. Secondly, the appointed consouling to the consouling unit do not belong to professional association. Third, the regulation of the Head of BKN and the Standard Operating Procedures govern the career- consouling unit not formalized in a clear and definitive regulation. Therefore, to boost the role of guidance and consouling, it's neccesary to have clear and definite regulations, to establish distinct consouling modules, to appoint certified counsellors belong to professional association, turn the image of consouling and bring in the civil servants, so they would use consouling services advancing their career.
\end{abstract}

Keywords: career counseling, counselor, counselee/ client, empowerment, counseling service unit

\section{INTRODUCTION}

Human Resources Planning is a process, through which the management of an organization may decide how it will move from the current human resources' position to the desired position and well into the future. Through Human Resources planning, the management will strive to obtain the correct number of and the types of human resources at the right place and at the right time so that it will optimize the organization's achievement, and at the same time each of the individual involved will get the benefit for a long time. The main challenge is how to manage the existing human resources effectively in the organization and eliminate any ineffective practices along the way [1]. The crucial aspect in the management human resources is how to empower the existing apparatus and to continue improving them in line with scientific and technological progress and the inevitable national and global competition.

The numerous issues plaguing bureaucracy in Indonesia, specifically those related to human resources management, must be handled in a proper, effective, and efficient manner. Thus, these issues must be handled in a serious manner. Therefore, it is crucial for each individual to have a full grasp with regard to the demand of his/her position and job and to pay attention to the career development program provided by the organization.

Nonetheless, activities related to career guidance and counseling currently mostly focus on the management of problematic employees. Therefore, so far counseling has not been able to meet the need of the individual or organization in full. In 2013, a special room has been designated solely for the purpose of the guidance and counseling session, and it was seen as a real effort to provide a professional guidance and counseling services to the employees, yet still it has not been optimized. The absence of Standard Operating Procedures (SOP) and the appointment of certified counselors from a professional association such as ABKIN (Asosiasi Bimbingan dan Konseling Indonesia) or the Association of Indonesian Guidance and Counseling are among the factors that hinder the optimal implementation of guidance and counseling activities within the organization. Another issue is the number of staff working at BKN main office, as there are 1,437 of them, yet throughout 2013, the guidance and counseling unit of the organization only managed four cases (two of the cases were actively managed). In 2014, there 
were four cases, and in 2015, the guidance and counseling unit only managed one case, and it was related to the case from the previous year. In 2015 because the position of the Head of Counseling and Performance was vacant, there were hardly any counseling activities at all. The counseling unit was also plagued by the misperception that counseling is reserved for employees with a mental or psychological problem, and there was hardly any information dissemination with regard to the actual role of the guidance and counseling unit within the organization.

From the above descriptions, we may formulate the following questions for this paper: What about the role of career guidance and counseling of civil servants at the Badan Kepegawaian Negara? How do we empower the role of career guidance and counseling in providing career guidance and counseling of civil servants at the Badan Kepegawaian Negara?

Human resources management is a process that seeks the optimal harmony between the employee or the worker, the job, the organization, and the environment, thus allowing the employee to achieve the level of satisfaction and performance that they desire and achieve the organization's objectives or goals as stated by Hall[2].

Individual members of the organization, the manager(s), and the organization itself all have roles to play in the planning and development of career, as stated [3], who explains that the roles on career development consist of: The roles of an individual which includes ; To bear the responsibility of his/her career; To have an interest, skills, and values; To be informed about the career and its resources; To prepare the planning and objective of the career; To utilize the opportunity for development; To consult the manager about the career; To follow a realistic career path. The roles of a manager are: To provide feedback at the appropriate time; To provide support and constructive assignment; To participate in a discussion about career development; To support the Employee Development Plan. The roles of the organization are: To communicate the mission policy and career procedures; To provide training and room for development; To provide information about career and related programs; To provide various.

[4], "Guidance is a process wherein an expert is providing an assistance to a single individual or a number of individuals, whether they are children, teenagers, or adults, so the person receiving the guidance may develop their own capacity and be independent by relying on their own individual strength as well as the existing facilities and those that can be developed according to the prevailing norms." From the aforementioned definition, it can be said that guidance and counseling are interconnected and influenced each other in their activities, which take on the form of a face to face meeting between individuals and are also a professional relationship between a trained counselor or an expert in the field to a counselee or client to assist them in adjusting, improve their attitude, assist them in achieving their own set of goals, self-determination, and develop their own potential towards a realistic career path both today and in the future.

\section{METHODOLOGY}

This study utilizes a post-positivist approach with a qualitative method. Informants for the study consisted of among others, counselor, structural officials with the relevant insight and knowledge, and involved in the career guidance and counseling activities, civil servants (PNS) as counselees/clients, and civil servants who take advantage of the career counseling unit. With regard to data processing, the raw data (verbatim) from the interviews are typed into transcript interviews.

\section{RESULT AND DISCUSSION}

From the location at the Subbag Kinerja dan Konseling Karier Pegawai (Sub-section of Performance and Employee Career Counseling) of the Bagian Kinerja dan Kesejahteraan (Performance and Welfare Section) of the Biro Kepegawaian BKN (BKN Personnel Bureau), the author obtained data in the form of transcripts interviews with the designated informants and used as the materials for analysis.

\section{Analysis on counseling's objectives}

From the information gained, the results achieved by the career-counseling unit at BKN based on the objectives can be stated as follows: Assisting and pushing towards a positive attitude change and improvement among the clients. Achieving a positive mental health, as seen from a case involving a client with mental disorder due to family problems, specifically about her husband; however, with the counselor's help and support from her children and parents as well as the extended family and friends at the office, the employee mental health has improved, even though she needs medication, yet I think the counselor has relatively been successful in managing the case such as this. Resolving client's problems is the 
main objective because it will make the client feel as if his/ her problems have been solved, unless in cases where the client is pretending to avoid disciplinary punishment. Last but not least, enabling the client to achieve personal effectiveness, namely by helping the client to make a decision on matters important to him/her and not wallowing in his/ her problems. The client can return to work, even though initially the client was going to be pensioned due to mental illness; however, the client is slowly improving and has returned back to work and will not be discharged honorably due to physical ailment.

\section{Analysis on counseling's success}

Broadly, the factors that influence a successful counseling are grouped into four, namely (1) the client factor, (2) the counselor factor, (3) the method or approach used, and (4) the place or room where the counseling session takes place. Based on the interviews with the informants on aspects related to successful counseling, we can state the following: Identification of the circumstances regarding a prospective client who is proposed by his/her superior. The selection or appointment of a counselor that does not involve the professional association due to the lack of focus with regard to counseling service or because the service is still attached to the performance and welfare section. The approach or method used for initiating a counseling session is based on the letter of the of the superior of the prospective counselee or client followed with a discussion with the counselee's superior and collecting information according to the stages and procedures established by the counseling team. Counseling session takes place in room 30306 located on the third floor of BKN building, and it is strictly used for a counseling session, so it is quite appropriate because it was specifically designed for the purpose. It was once used as an office for a former official and not as a counseling room.

\section{Analysis to determine the types of counseling}

The types of counseling are determined by combining the directive and non-directive counseling methods to resolve the issues and if necessary by collecting information from other individuals or enlisting help from other relevant individuals.

\section{Analysis to determine stages of counseling \\ The stages of counseling begin with the preliminary session where the counseling unit}

attempts to make the counselee comfortable, and an agreement is reached to continue with a counseling session. The mid-session is when information about the individuals affecting the counselee's issues is collected, and in the final stage the story is reviewed from beginning to the end and they discuss what can be done on daily basis with the expectation that the counselee will perform better at work.

\section{Analysis on Empowering the Counseling Service Unit}

The next discussion touches the topic on how to empower the career counseling service unit at $\mathrm{BKN}$ based on the application of theory by the author and interviews with the informants. The career counseling service unit at BKN refers to the organization's vision and mission namely that the organization shall consider and connect employees' potential. Career guidance and counseling are inseparable from the career pattern system and the employee career development pattern. The close relationship between a superior and their subordinates will create an active communication forum and will be beneficial in resolving the subordinates' career issues, and for cases that need special handling they can be referred to the career counseling service unit. The career counseling service unit at $\mathrm{BKN}$ is needed both by the individual staff and employees and by the organization advancing employees' career and resolving issues that may influence or even become detrimental towards employees' performances. With regard to its role to promote individual development, the career counseling service unit should have a database on job competence listing the competence and gap of individuals in the organization that would be beneficial in employee development. Career guidance and counseling play a major role in determining whether an employee will be classified as gold or bronze or even iron. Data on employees' competence can be classified and made into a talent pool, and this is being done at the moment. The counseling service unit does not focus on career counseling, whereas the Human Resources counseling also still focuses on problematic employees and staff including those with mental or psychological disorder. Career counseling service is tailored according to needs, such as career consultation, psychology, retirement, pre-retirement, pre or post-divorce, counseling education, e-counseling, seminars, talent and interest scouting for employees' children, yet they are not optimized. With regard to the common 
practice in the institutional unit, the civil servant counseling unit at BKN should be empowered to regulate its practice such as deciding on the time or the type of services.

\section{CONCLUSION}

The service does not focus solely on career counseling because in addition to handling psychological counseling, the service also provides services to clients with mental or psychological disorder to be referred to a psychiatrist. This proves to be detrimental to the image of career counseling among civil servants at BKN because of the perception that the counseling unit is for problematic employees only, including those with mental or psychological disorder and not about career consultation, i.e. assisting an employee with an impasse with his/her career, career obstacles, and assisting an employee to achieve his/her career goal.

The Regulation of the BKN Head and the Standard Operating Procedures that govern the career counseling service unit are not standardized or formalized in a clear and definite regulation. The service does not solely focus on career counseling; therefore, the unit cannot fulfill its intended function, not to mention a lack luster support from the leadership as apparent from the budgeting and the lack of database on employee competence to map the employee and staff as part of regular activities in the career counseling unit.

To maximize counseling services that focus on employees' career and not only psychological counseling or counseling civil servants with mental or psychological disorder. To disseminate the fact about the counseling unit and turn its negative image, so more employees will come for consultation or for information or career assistance. To empower the managers or leaders at echelon 3 level so they will have the necessary skills or competence to counsel their subordinates. BKN should grant access to the counseling unit to use the database on employee competence, thus allowing the unit to work more effectively in identifying employees and staff that may be in need of counseling. There is a need to set up a module as guidelines so the activities on career guidance and counseling will focus more, with a clear and definite objective and definition of services. With regard to the existing condition since the current term of career counseling matched the spirit of the Regulation Number 19 of the year 2014 (Perka 19), it may be necessary to reconsider the term of career counseling at $\mathrm{BKN}$ and change it into career coaching or Pembinaan Karir PNS (Civil Service Career Development). Therefore, the name career counseling unit will be changed into Civil Service Career Development, wherein the unit will be assigned with the task to nurture civil servant career, whereas cases related to mental or psychological disorders shall be managed by a special bureau that manages a psychological case like that, and the services on career consultation will no longer be mixed with other psychological disorders thus enabling the service to be more effective and beneficial for the individual or the organization.

\section{ACKNOWLEDGMENT}

This paper is part of the published section of the final assignment, and the publication of this paper is funded by PITTA Grant from Universitas Indonesia.

\section{REFERENCES}

[1] Sedarmayanti, Prof. Dr. (2007), Manajemen Sumber Daya Manusia, Reformasi Birokrasi, dan Manajemen Pegawai Negeri Sipil, Bandung PT. Refika Aditama.

[2] Hall T. Douglas \& James Goodale G. (1986), Human Resources Management, Strategy Design and Implementation, Glenview: Scott Foresman and Company.

[3] Dessler, Gery. (2006), Manajemen Sumber Daya Manusia, Tenth Edition, Jakarta: PT. Indeks

[4] Prayitno, Prof. Dr. \& Amti, Erman (2004), Dasar-Dasar Bimbingan dan Konseling. Jakarta: PT. Rineka Cipta. 